\title{
The Occurrence of Emerging Human Pathogen Shewanella algae in Shrimp Seafood
}

\author{
Chandraval Dutta ${ }^{*}$, Sanjib Kumar Manna ${ }^{2}$ and Chandan Sengupta ${ }^{3}$ \\ ${ }^{1}$ Department of Zoology, University of Kalyani, Kalyani, Nadia-741235, West Bengal, India \\ ${ }^{2}$ ICAR-Central Inland Fisheries Research Institute, Barrackpore-700 120, West Bengal, India \\ ${ }^{3}$ Microbiology Laboratory, Department of Botany, University of Kalyani, \\ Kalyani, Nadia-741235, West Bengal, India \\ *Corresponding author
}

\section{A B S T R A C T}

Keywords

Shewanella algae, shrimp, West

Bengal, India, prevalence

Article Info

Accepted:

23 April 2020

Available Online:

10 May 2020
Shewanella algae is an emerging pathogen with an increasing rate of association in clinical samples worldwide. Exposure to marine and brackish waters has frequently been linked to human infection. The present study has examined the prevalence of the bacterium in shrimp which is a brackish water crop. The bacterium was isolated from about $8 \%$ of the shrimps' samples cultured and sold in different parts of West Bengal, India. The isolates produced hemolysin and were thus considered virulent. An increase in the occurrence of human infections caused by $S$. algae and a significant presence of the bacterium in shrimp warrants need for higher surveillance of the pathogen in clinical samples.

\section{Introduction}

Shewanella algae are one of the emerging bacterial pathogens (Dey et al., 2015). The bacterium causes a wide range of human infections from acute gastroenteritis to osteomyelitis, skin and soft tissue ulcer, ear and eye infection, inflammation conditions of bones and joints with pre-existing wounds which may lead to bacteraemia and sepsis, especially among immuno-compromised patients from different parts of the world (Nozue et al., 1992; Domı'nguez et al., 1996; Holt et al., 1997; Botelho-Nevers et al., 2005; Jampala et al., 2015; Shu-Ying-Tseng et al., 2018).

In association with other pathogens, it has been implicated in neonatal sepsis, meningitis, pneumonia, infective 
endocarditic, post-operative peritonitis and chronic obstructive pulmonary disease (COPD) with acute exacerbation (Dhawan et al., 1998; Mukhopadhay et al., 2007; Charles et al., 2015; Torri et al., 2018). Although the majority of the $S$. algae isolates show susceptibility to aminoglycosides, quinolones, third-generation cephalosporins, and $B$ lactamase inhibitors, resistance to multiple antibiotics or antimicrobials are increasingly been reported raising serious concerns (Holt et al., 2005; Botelho-Nevers et al., 2005; Jampala et al., 2015). The bacterium produces a battery of virulence factors such as adhesion, lipopolysaccharide, siderophores, production of exoenzyme, hemolysins and tetrodotoxins (Martino et al., 2003; Paździor, 2016).

Several Shewanella species are a natural inhabitant of marine and brackish water but can adapt to freshwater (Winn et al., 2006) and fish, shellfish and other seafood have been reported to harbor the bacterium (S.Y. Tseng et al., 2018). S. algae have been detected from human borne illness while other species, especially, S. putrifaciens is more associated with fish disease. In Japan, the bacterium was originally isolated from red alga which produces tetrodotoxin (Simidu et al., 1990) and the incidences of Shewanella infection were increased drastically in the following years due to consumption of raw fish (Otsuka et al., 2007). Furthermore, individuals with hepatobiliary diseases have been more infected with $S$. algae infection from ingestion of raw seafood in Asian countries like Japan, China, Vietnam, Thailand, etc. (Liu et al., 2013; Tseng et al., 2018). As such, water, fish and shellfish might be the major sources of the bacterium to human.

Human cases of $S$. algae infection are increasingly being reported from India and other countries in recent years. Increasing water temperature due to global warming has been linked to it (Bauer et al., 2019); making people of tropical countries more prone to the infection than their temperate counterparts (Tseng et al., 2018; Bauer et al., 2019).

Exposure to the marine environment and consumption of seafood has frequently been associated with human infections. Shrimp is one of the most traded items globally with an annual turnover of almost 4 million tonnes in 2018 (FAO, 2018). West Bengal is maritime and one of the major shrimp producing states of India with an annual production of 76543 tonnes during FY 2017-18 and whereas in India the annual production of shrimp and prawn was 682142 metric tonnes in quantity during 2018-19(MPEDA, Govt. of. India). The per capita consumption of fish and shellfish was $9 \mathrm{~kg}$ during 2017-18 (DOF, Govt. of India). S. algae infection in humans has also frequently been reported from this country, suggesting a probable link between human infection and shrimp (Jampala et al., 2015). The objective of this study was to examine the prevalence of $S$. algae in shrimps to find a probable source of human infection and towards the safety of the shrimp growers, sellers and consumers.

\section{Materials and Methods}

\section{Sample collection}

A total of 112 fresh shrimp samples which included Penaeus monodon, $P$. indicus, $L$. vannamei were collected from different domestic retail markets in and around Kolkata, West Bengal.

These shrimps are produced locally in coastal districts of the states and a part of the product is marketed fresh locally. The samples were kept in sterile plastic bags, brought to the laboratory under ice cover and processed without delay. 


\section{Bacterial isolation}

The whole shrimp samples were cut into small pieces by sterile scissors. The muscles, gut, hepato-pancreatic tissues were homogenized to $10 \% \mathrm{w} / \mathrm{v}$ in sterile PBS and 5 $\mathrm{ml}$ of the homogenate was enriched in $100 \mathrm{ml}$ marine broth(MB) 2216 (BD Difco ${ }^{\mathrm{TM}}$, USA). After $48 \mathrm{~h}$ incubation at $30^{\circ} \mathrm{C}$ a loop full of enrichment culture was streaked on to marine agar (MA) 2216 (BD Difco ${ }^{\mathrm{TM}}$, USA) and incubated at $30^{\circ} \mathrm{C}$ for 2 days. Orange-yellow or pink colonies with smooth, circular and convex surface and entire margin were selected and grown to pure culture (Tseng et al., 2018).

\section{Identification of the bacteria}

The bacterial isolates were identified by Gram staining, biochemical reactions such as oxidase, catalase reaction, hydrogen sulfide $\left(\mathrm{H}_{2} \mathrm{~S}\right)$ and indole production, utilization of carbohydrate (arabinose, glucose, and sucrose) and fatty acids, growth in $6.5 \%$ $\mathrm{NaCl}$ following standard methodologies (Khashe and Janda 1998; Vogel et al., 2005).

\section{Molecular identification of bacteria}

The bacterial gene encoding 16S rRNA was PCR amplified using universal bacterial $27 \mathrm{f}$ (5'-AGAGTTTGATCCTGGCTCA G-3') and 1492r (5'- GGTTACCTTGTTACGACTT-3') primers. The template DNA was obtained by extracting the genomic DNA using the GenElute Bacterial Genomic DNA kit (Sigma-Aldrich) from a fresh colony grown on marine agar 2216. The PCR reaction was performed in $50 \mu \mathrm{l}$ volume containing $25 \mu \mathrm{l}$ of Red Taq Ready Mix (Sigma), $0.2 \mu$ each of forward \& reverse primers and template DNA. The following cycle was used for PCR reaction: initial denaturation at $95^{\circ} \mathrm{C}$ for 1 minute, followed by 30 cycles at $95^{\circ} \mathrm{C}$ for 30 seconds, $57^{\circ} \mathrm{C}$ for 30 seconds, $72^{\circ} \mathrm{C}$ for 2 minutes and a final extension at $72^{\circ} \mathrm{C}$ for 5 minutes. The PCR products were visualized on a $1.5 \%$ agarose gel; a 100 bp DNA ladder (Sigma) was included on each gel for product size estimation. PCR products were gel purified using a QIAquick gel extraction kit (Qiagen) and sequenced by the Sanger sequencing method. Sequenced data were edited and aligned using CodonCode Aligner software. The identification of the isolates was determined following the BLAST search of sequence homology in NCBI GenBank and RDP databases. The phylogenic tree of the identified bacteria from the nearly complete 16S rDNA gene sequences was prepared with gene sequences of reference/type strains using MEGA6 software.

\section{Haemolysin production}

Haemolysin production by the bacterial isolates was examined by streaking of bacteria on 5\% sheep blood agar (HiMedia, India). The plates were incubated at $37^{\circ} \mathrm{C}$ and examined for hemolytic activity.

\section{Results and Discussion}

A total of 14 presumptive Shewanella bacterial strains were initially isolated from 112 shrimp samples. Based on cell morphology and biochemical reactions 11 strains, isolated from a total of 9 samples, were identified as $S$. algae. The prevalence of Shewanella sp. in different shrimp species collected from different markets of West Bengal is given in Table 1. The bacteria were detected in all the shrimp species examined: $8.11 \%$ of Penaeus monodon, $11.76 \%$ of $P$. indicus, and $4.76 \%$ of $L$. vannamei shrimp samples were contamination with $S$. algae.

The identified $S$. algae strains were oxidasepositive, indole negative, citrate-negative, urease positive, produced black coloration in butt portion of Triple Sugar Iron agar slant 
due to hydrogen sulfide $\left(\mathrm{H}_{2} \mathrm{~S}\right)$ production. The isolates had grown on SalmonellaShigella agar (SS agar) at $42{ }^{\circ} \mathrm{C}$, and in presence of $6.5 \% \mathrm{NaCl}$ and were betahemolytic on $5 \%$. sheep blood agar, but failed to produce acid from sucrose, maltose, and arabinose. Detailed biochemical reactions of three strains are given in Table 2.

Identification of the isolates was further confirmed from 16S rDNA sequences and three sequences have been submitted to the GenBank database (Accession nos. JQ265998, JQ26605, and JQ266007). The $16 \mathrm{~S}$ rDNA sequences of the isolates showed the highest $\%$ identity with $S$. algae and moderate genetic distance from some of the other Shewanella species reported from different parts of the world (Fig. 1).

This is possibly the first report showing the presence of S. algae in shrimp. Shrimp is one of the commonly available, affordable and most traded seafood globally as well as in this part of India and the presence of this emerging human pathogen raises a serious public health concern. The bacterium was detected in as many as $8 \%$ of the shrimp samples tested, which matches the findings of Tseng et al., (2018).

Table.1 Prevalence of $S$. algae in different shrimp samples examined

\begin{tabular}{|c|c|c|c|c|c|c|}
\hline & $\begin{array}{l}\text { Scientific } \\
\text { name }\end{array}$ & Habitat $^{\mathrm{a}}$ & $\begin{array}{l}\text { Place of } \\
\text { sample } \\
\text { collection }\end{array}$ & $\begin{array}{c}\text { Number } \\
\text { of } \\
\text { samples } \\
\text { examined }\end{array}$ & $\begin{array}{c}\text { Number of } \\
\text { samples } \\
\text { contaminated }\end{array}$ & $\begin{array}{l}\text { Percentage of } \\
\text { Samples } \\
\text { contaminated }\end{array}$ \\
\hline $\begin{array}{l}\text { Tiger } \\
\text { shrimp }\end{array}$ & $\begin{array}{l}\text { Penaeus } \\
\text { monodon }\end{array}$ & $\begin{array}{l}\text { Marine \& } \\
\text { estuarine } \\
\text { water }\end{array}$ & $\begin{array}{l}\text { Garia } \\
\text { (Kolkata) }\end{array}$ & 20 & 0 & 0.00 \\
\hline $\begin{array}{l}\text { White } \\
\text { shrimp }\end{array}$ & P. indicus & $\begin{array}{l}\text { Marine \& } \\
\text { estuarine } \\
\text { water }\end{array}$ & do & 6 & 1 & 6.25 \\
\hline $\begin{array}{l}\text { Vannamei } \\
\text { shrimp }\end{array}$ & L. vannamei & $\begin{array}{l}\text { Marine \& } \\
\text { coastal water }\end{array}$ & do & 12 & 0 & 0.00 \\
\hline $\begin{array}{l}\text { Tiger } \\
\text { shrimp }\end{array}$ & P. monodon & $\begin{array}{l}\text { Marine \& } \\
\text { coastal water }\end{array}$ & $\begin{array}{l}\text { Sealdah } \\
\text { (Kolkata) }\end{array}$ & 20 & 2 & 10.00 \\
\hline $\begin{array}{l}\text { Tiger } \\
\text { shrimp }\end{array}$ & P. monodon & $\begin{array}{l}\text { Marine \& } \\
\text { estuarine } \\
\text { water }\end{array}$ & $\begin{array}{l}\text { Diamond } \\
\text { Harbour }\end{array}$ & 18 & 3 & 16.66 \\
\hline $\begin{array}{l}\text { Tiger } \\
\text { Shrimp }\end{array}$ & P. monodon & $\begin{array}{l}\text { Marine \& } \\
\text { coastal water }\end{array}$ & Kakdwip & 16 & 1 & 6.25 \\
\hline $\begin{array}{l}\text { White } \\
\text { Shrimp }\end{array}$ & $\begin{array}{l}P . \\
\text { indicus }\end{array}$ & $\begin{array}{l}\text { Marine \& } \\
\text { coastal water }\end{array}$ & $\begin{array}{l}\text { Sealdah } \\
\text { (Kolkata) }\end{array}$ & 11 & 1 & 9.09 \\
\hline $\begin{array}{l}\text { Vannamei } \\
\text { Shrimp }\end{array}$ & L. vannamei & $\begin{array}{l}\text { Marine \& } \\
\text { estuarine } \\
\text { water }\end{array}$ & Namkhana & 9 & 1 & 11.11 \\
\hline \multicolumn{4}{|c|}{ Total } & 112 & 9 & 8.04 \\
\hline
\end{tabular}

${ }^{a}$ Habitat of the shrimp species as per record 
Table.2 Biochemical characteristics of S. algae strains

\begin{tabular}{|l|c|c|c|}
\hline \multirow{2}{*}{ Test } & \multicolumn{3}{|c|}{ Bacterial strain ID } \\
\hline Oxidase & KUGWB02 & KUHWB220 & KUKWB16 \\
\hline Catalase & + & + & + \\
\hline $\begin{array}{l}\text { Ornithine } \\
\text { decarboxylase }\end{array}$ & + & + & + \\
\hline OF (Glucose) & Oxidation & Oxidation & Oxidation \\
\hline $\begin{array}{l}\text { Acid production from } \\
\text { glucose }\end{array}$ & - & - & - \\
\hline Acid from arabinose & - & - & - \\
\hline Acid from sucrose & - & - & - \\
\hline H2S production & + & + & + \\
\hline Growth in 6.5\% NaCl & + & + & + \\
\hline Indole production & - & - & - \\
\hline Urease & + & + & + \\
\hline Beta Hemolysis & + & + & + \\
\hline
\end{tabular}

a (+) indicates positive reaction, (-) indicates negative reaction

Table.3 Summary of human case reports of S. algae infection in India

\begin{tabular}{|c|c|c|c|c|c|c|}
\hline City & Year & $\begin{array}{l}\text { Number of } \\
\text { affected } \\
\text { persons }\end{array}$ & Comorbidities & Sign/Symptom & $\begin{array}{l}\text { Exposure to } \\
\text { seawater/ } \\
\text { seafood }\end{array}$ & Reference \\
\hline $\begin{array}{c}\text { Manipal, } \\
\text { Karnataka }\end{array}$ & 2007 & 02 & - & $\begin{array}{l}\text { Vomiting, } \\
\text { abdominal pain, } \\
\text { Pneumonia }\end{array}$ & No & $\begin{array}{l}\text { Mukhopadhyay } \\
\text { et al., } 2007\end{array}$ \\
\hline $\begin{array}{c}\text { Tirupati } \\
\text { Andhra Pradesh }\end{array}$ & 2010 & 05 & $\begin{array}{l}\text { Diabetes, cellulities, ulcers, } \\
\text { breast carcinoma, diarrhoea }\end{array}$ & $\begin{array}{c}\text { Ulcers, } \\
\text { Gastroenteritis }\end{array}$ & unknown & $\begin{array}{l}\text { Sharma et al., } \\
2010\end{array}$ \\
\hline Delhi & 2011 & 01 & Non healing ulcers & Ulcers & unknown & $\begin{array}{c}\text { Goyal et al., } \\
2011\end{array}$ \\
\hline $\begin{array}{c}\text { Dibrugarh , } \\
\text { Assam }\end{array}$ & $\begin{array}{l}2010- \\
2011\end{array}$ & 02 & none & Bloody Diarrhoea & Fish & Nath et al., 2011 \\
\hline $\begin{array}{l}\text { Bengaluru } \\
\text { Karnataka }\end{array}$ & 2014 & 01 & $\begin{array}{l}\text { Chronic draining } \\
\text { osteomyelitis }\end{array}$ & $\begin{array}{l}\text { Squamous cell } \\
\text { carcinoma }\end{array}$ & water & $\begin{array}{l}\text { Sumathi et al., } \\
2014\end{array}$ \\
\hline $\begin{array}{c}\text { Hubli } \\
\text { Karnataka }\end{array}$ & 2012 & & none & $\begin{array}{c}\text { Acute } \\
\text { gastroenteritis, } \\
\text { bloody diarrhoea }\end{array}$ & unknown & Dey et al., 2015 \\
\hline Kochi, Kerala & $\begin{array}{l}2010- \\
2014\end{array}$ & & $\begin{array}{l}\text { Hypertension, peripheral } \\
\text { vascular occlusive disease, } \\
\text { Hypertension Diabetes }\end{array}$ & $\begin{array}{l}\text { Chronic ulcer, } \\
\text { Gangrene and } \\
\text { cellulitis of left toe }\end{array}$ & no & $\begin{array}{l}\text { Jampala et al., } \\
2015\end{array}$ \\
\hline Pondichery & 2015 & & Newborn & Sepsis & No & $\begin{array}{l}\text { Charles et al., } \\
\quad 2015\end{array}$ \\
\hline
\end{tabular}




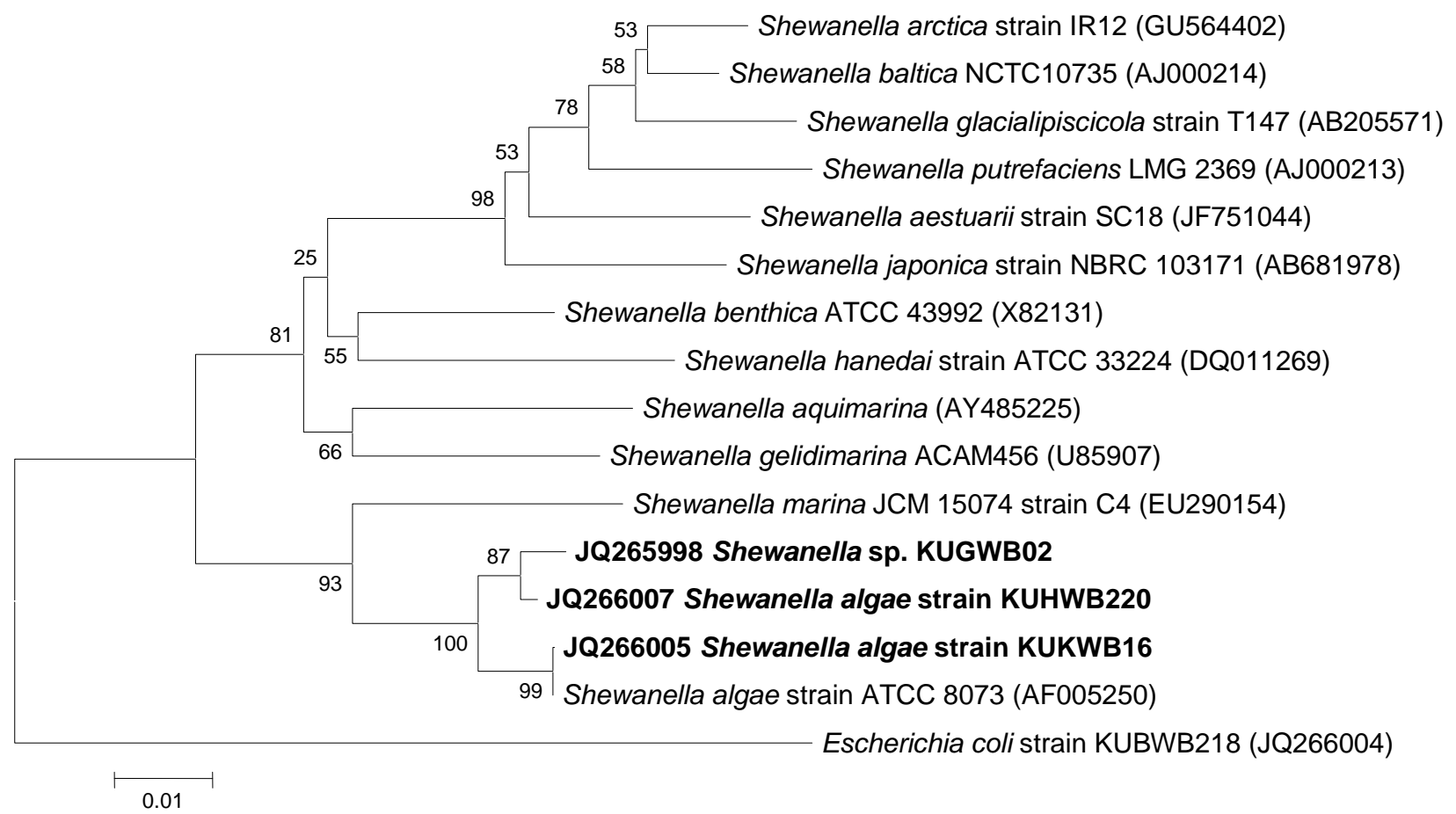

Fig.1 Phylogenetic tree of S. algae strains constructed by the neighbor-joining method (Saitou N. and Nei, 1987) and 1000 bootstrap replicates. Taxonomic positions of the present isolates (shown in bold) are compared with reference strains of few other Shewanella species. The evolutionary distances were computed by MEGA 6 (Tamura et al., 2013) program using the Kimura 2-parameter method (Kimura, 1980)

Members of the genus Shewanella are widely found in marine and brackish water environments which include benthic and intertidal zones, sediments, terrestrial environments, oilfield wastes (Melvold, 2017). These shrimps are cultured in brackish water and it is assumed that the bacterium has come to shrimp from its culture environment. However, Shewanella can well adapt to freshwater environments and has been detected from the freshwater tilapia fish farm (Lu and Levin, 2010). In the present study, the bacterium was detected in all the shrimp species examined, with a higher presence in $P$. indicus and lower presence in L. vennamei. However, due to an insufficient number of total and contaminated samples, the difference in the level of contamination in different shrimp species was insignificant and we consider all the three species more or less equally contaminated.
The genus Shewanella is a gram-negative, oxidase-positive, catalase-positive, $\mathrm{H}_{2} \mathrm{~S}$ producing bacillus. $S$. algae and $S$. putrifaciens are two prominent species which have been studied in environmental samples, fish, and human, etc. The main distinguishing features between two species are S. algae can grow at $42{ }^{\circ} \mathrm{C}$ and in $6 \% \mathrm{NaCl}$ and reduces nitrate, and does not produce acid from maltose (Holt et al., 2005).

The present isolates showed typical biochemical reactions which were one of the bases of their identification as $S$. algae. Although $S$. algae produce several virulence factors, hemolysin production is easy to test and has often been found in clinical isolates (Holt et al., 2005). A good number of $S$. algae isolates show $\beta$-hemolysis on $5 \%$ blood agar after 72 incubation at $37^{\circ} \mathrm{C}$; production of hemolysin is a virulence mechanism and has 
been correlated with clinical occurrences and severity of infection (Charles et al., 2015).

Different Shewanella species have been identified from the gut of several wild caught Mediterranean fish species and were able to colonize the gut of zebrafish in an exposure study indicating the presence of the bacteria as part of fish gut microflora (Jammal et al., 2017). S. putrefaciens, a common halophilic species associated with fish spoilage, cause skin disorders and haemorrhages in internal organs of marine and freshwater fishes (Koziñska and Pekala 2004; Paździor, 2016). Unlike $S$. putrefaciens, $S$. algae have often been associated with human infections.

The present isolates produced hemolysin suggesting their virulent nature and there is a strong possibility that they might be associated with human infections. Table 3 shows that $S$. algae have been associated with several human ailments in India in last one decade: although a source of infection was not traced in many cases, the predominance of such cases in coastal and fish-eating states suggest a possible association of water and/or fish/shellfish with human infections. Seafood has been identified as the source of infection in a few cases (Nath et al., 2011).

During the period from 1999 to 2017, a large number of $S$. algae infection cases have been reported from Asian countries like China, Japan, Malaysia and Iran, and water was an important source of contamination in $64 \%$ of cases (Tseng et al., 2018). In India also Shewanella algae have been implicated in serious health hazards in humans like bacteraemia, otitis media, cellulitis, gastroenteritis, abscesses, soft tissue infections and wound infections directly through the exposure of seawater or consumption of raw seafood (Dey et al., 2015).
Although the bacterium often causes disease with other pathogens, S. algae were the only pathogen in about $60 \%$ of human cases (Melvold, 2017). S. algae infections are more common in immuno-compromised patients, however, severe necrotizing fasciitis and bacteraemia have been recorded in healthy but stressed individuals exposed to sea with warmer water temperatures making it a potentially virulent organism (Bauer et al., 2019).

There is a possibility that Shewanella infection is under-reported in developing countries like India due to lack of adequate infrastructure facilities for proper identification of this rare bacteria and lack of awareness which creates misidentification of this bacteria as Pseudomonas sp. (Shamanna et al., 2018). The prevalence of the bacterium in about $8 \%$ of shrimp, which is very popular and affordable seafood, is quite high and alarming. This raises a significant risk of infection not only of the consumers but also for fish farmers and those involved in shrimp processing and marketing.

Thus, there is a need for increased surveillance for this pathogen in human clinical samples. Proper cooking, cleaning of processing and kitchen environments, and high level of personnel hygiene are recommended to reduce the chance of $S$. algae infection.

\section{References}

Bauer, M.J., Stone-Garza K.K., Croom, D. ; Andreoli, C., Woodson, P., Graf , P.C.F., and Maves R.C. (2019) Shewanella algae Infections in United States Naval Special Warfare Trainees. Infectious Diseases Society of America. DOI: 10.1093/ofid/ofz442.

Botelho-Nevers, E., Gouriet, F., Rovery, C., Paris, P., Roux ,V., Raoult, D. and Brouqui ,P. (2005) First Case of Osteomyelitis Due to 
Shewanella algae. Journal of Clinical Microbiology 43(10): 5388-5390.

Charles, M.V.P., Srirangaraj, S., Kali, A. (2015) Neonatal sepsis caused by Shewanella algae: A case report. Australasian Medical Journal (AMJ) 8(2):64-66.

Department of Fisheries, Government of India (2019) Handbook of Fisheries Statistics 2018 Ministry of Fisheries, Animal Husbandry and Dairying, Krishi Bhaban, New Delhi. http://dof.gov.in/sites/default/ filess/Handbook\%20on\%20FS\%202018.pd $\mathrm{f}$

Dey, S., Bhattacharya, D., Roy, S., Nadgir, S.D., Patil, A., Kholkute, S.D. (2015) Shewanella algae in acute gastroenteritis. Indian Journal of Medical Microbiology 33:172175.

Dhawan, B., Chaudry, R., Mishra, B.M. and Agarwal, R. (1998) Isolation of Shewanella putrefaciens from a Rheumatic Heart Disease Patient with Infective Endocarditis. Journal of Clinical Microbiology. 36: 23946

Dom'inguez, H., Vogel, B. F., Gram, L., Hoffmann, S. and Schaebel, S. (1996) "Shewanella alga bacteremia in two patients with lower leg ulcers," Clinical Infectious Diseases, 22(6): 1036-1039.

FAO (2018) The state of World Fisheries and Aquaculture Food and Agriculture Organization of the United Nation, Rome Italy, http://www.fao.org/inaction/globefish/market-reports/resourcedetail/en/c/1199292/

Goyal R, Kaur N. and Thakur R. (2011) Human soft tissue infection by the emerging pathogen Shewanella algae. The Journal of Infection in Developing countries.,5(4):310312.

Holt, H. M., Gahrn-Hansen, B. and Bruun, B.( 2005) "Shewanella algae and Shewanella putrefaciens: clinical and microbiological characteristics," Clinical Microbiology and Infection, 11(5): 347-352.

Holt, H. M., Søgaard, P. and Gahrn-Hansen, B. (1997) "Ear infections with Shewanella alga: a bacteriologic, clinical and epidemiologic study of 67 cases," Clinical Microbiology and Infection,3(3): 329333.http// doi.org/10.1155/2018/6976897
Jammal, A., Bariche, M., Dohna, H. Z. and Kambris, Z. (2017) Characterization of the cultivable gut microflora in wild-caught Mediterranean fish species. Current Nutrition \& Food Science, 13:147-154.

Jampala, S., Meera, P., Vivek, V., Kavitha , D.R.(2015) Skin and soft tissue infection due to Shewanella algae -an emerging pathogen. Journal of Clinical and Diagnostic Research 9(2):5

Khashe, S. and. Janda, J. M. (1998) "Biochemical and pathogenic properties of Shewanella alga and Shewanella putrefaciens,"Journal of Clinical Microbiology, 36(3): 783-787.

Kimura, M. (1980). A simple method for estimating evolutionary rate of base substitutions through comparative studies of nucleotide sequences. Journal of Molecular Evolution 16:111-120.

Koziñska, A. and Pekala, A. (2004) First isolation of Shewanella putrefaciens from freshwater fish - a potential new pathogen of fish. Bulletin of the European Association of Fish Pathologists, 24(4): 189-193.

Liu, P.-Y. ; Lin C.-F., Tung, K.-C. et al., (2013) "Clinical and microbiological features of Shewanella Bacteremia in patients with hepatobiliary disease," Internal Medicine, 52(4): 431-438,.

Lu, S. and Levin, R.E. (2010) Shewanella in a tilapia fish farm. Journal of FisheriesScience.com, 4(2): 159-170.

Martino, P. D., Fursy, R., Bret, L., Sundararaju, B.and Phillips, R. S.(2003) "Indole can act as an extracellular signal to regulate biofilm formation of Escherichia coli and other indole-producing bacteria," Canadian Journal of Microbiology, 49(7): 443-449.

Melvold, J.A. (2017) The characherisation of Shewanella algae $\mathrm{PhD}$ thesis, University of Technology Sydney, Australia.

MPEDA, Government of India (2018) State wise details of shrimp and scampi production2017-18 Marine Product Export Development Authority, Government of India. Retrieved from https://www.mpeda.gov.in/MPEDA/cms.ph p?id=eWVhci13aXNILXNwZWNpZXMtd 2lzZS1zdGF0ZS13aXNl\#

Mukhopadhyay, C., Chawla, K., Sharma, Y. and Bairy, I. (2007) First Report of Shewanella 
alga as Emerging Infection in India: Two Cases. Journal of Clinical and Diagnostic Research. Aug; 1(4): 293-295.

Nath, R., Choudhury, G., Saikia, L. and Das, P. (2011) "Isolation of Shewanella algae from rectal swabs of patients with bloody diarrhoea," Indian Journal of Medical Microbiology, 29(4): 428.

Nozue, H., Hayashi, T., Hashimoto, Y. et al., (1992) "Isolation and characterization of Shewanella alga from human clinical specimens and emendation of the description of $S$. alga Simidu et al., 1990, 335," International Journal of Systematic Bacteriology,. 42(4): 628-634.

Otsuka, T., Noda, T. ;Noguchi, A., Nakamura, H., Ibaraki, K. and Yamaoka, K.(2007) "Shewanella infection in decompensated liver disease: a septic case," Journal of Gastroenterology, 42(1): 87-90.

Paździor, E. (2016) Shewanella putrefaciens - a new opportunistic pathogen of freshwater fish. Jounal of Veterinary Research 60: 429-434.

Saitou, N. and Nei, M. (1987). The neighborjoining method: A new method for reconstructing phylogenetic trees. Molecular Biology and Evolution 4:406-425.

Shamanna, P., Ravindran, J., Lalremruati, J. and Sethumadavan, M. (2018) Emerging Pathogen: Shewanella Algae causing Burn Wound Infection - Report of Two Cases from a Tertiary Care Center. International Journal of Current Microbiology and Applied Sciences. 7(05): 48-53. doi: https://doi.org/10.20546/ijcmas.2018.705.0 07
Sharma, K.K .and Kalawat, U. (2010) Emerging infections: Shewanella-A series of five cases. Journal of Laboratory Physicians 2(2): 61-65.

Simidu, U., Kita-Tsukamoto, K., Yasumoto, T. and Yotsu, M. (1990) Taxonomy of four marine bacterial strains that produce tetrodotoxin International journal of Systematic Bacteriology. 40(4):331-336.

Sumathi, B. G., Kumarswamy, S. R., Amritam, U. and Arjunan, R. (2014) "Shewanella algae: first case report of the fast emerging marine pathogen from squamous cell carcinoma patient in India," South Asian Journal of Cancer, 3(3): 188-189.

Tamura, K., Stecher, G., Peterson, D., Filipski, A. and Kumar S. (2013). MEGA6: Molecular Evolutionary Genetics Analysis version 6.0. Molecular Biology and Evolution 30: 2725-2729.

Torri, A., Bertini, S., Schiavone, P. et al., (2018) Shewanella algae infection in Italy: report of 3 years' evaluation along the coast of the northern Adriatic Sea. New Microbes and New Infections 23:39-43.

Tseng, S.Y., Liu, P.Y., Lee, Y.H., Wu, Z.Y., Huang, C.C., Cheng, C.C. and Tung, K.C. (2018) The pathogenicity of Shewanella algae and ability to tolerate a wide range of temperature and salinities Canadian Journal of Infectious Diseases and Medical Microbiology 2018:1-9

Winn, W. Jr., Allen, S., Janda, W., Koneman, E., Procop, G., Schrenberger, P., Woods, G. (2006) Koneman's colour Atlas and textbook of Diagnostic microbiology. 6th ed. Lippincott Williams and Wilkins (USA). Pp. 303-391.

\section{How to cite this article:}

Chandraval Dutta, Sanjib Kumar Manna and Chandan Sengupta. 2020. The Occurrence of Emerging Human Pathogen Shewanella algae in Shrimp Seafood. Int.J.Curr.Microbiol.App.Sci. 9(05): 2677-2685. doi: https://doi.org/10.20546/ijcmas.2020.905.307 